Research Article

\title{
Different Doses of Intraumbilical Oxytocin on the Third Stage of Labor
}

\author{
Berbagai Dosis Oksitosin Intraumbilikal pada Manajemen Aktif Kala III \\ Nurul Islamy1, Nuswil Bernolian', Firmansyah Basir'1, Theodorus ${ }^{2}$ \\ ${ }^{1}$ Department of Obstetrics and Gynecology \\ ${ }^{2}$ Public Health and Research Unit \\ Faculty of Medicine Universitas Sriwijaya/ \\ Dr. Mohammad Hoesin Hospital \\ Palembang
}

\begin{abstract}
Objective: To compare the dose of oxytocin injected intraumbilicall towards the duration of the third stage, blood loss volume, hemoglobin and hematocrit.

Methods: This study is a prospective randomised study with a control. The control group was given an intramuscular injection of $10 \mathrm{IU}$ oxytocin. The intervention of the three groups intraumbilical oxytocin treatment dose of $10 \mathrm{IU}, 20 \mathrm{IU}$ and $30 \mathrm{IU}$ diluted in $50 \mathrm{ml}$ of normal saline solution and administered intraumbilically. The sample selection by purposive sampling and the distribution group based on systematic random sampling (10 samples each). Data were taken from the period April 2016-January 2017 with the inclusion and exclusion criteria. Data were analysed using Chi-square, T-test, ANOVA and Post hoc tests.
\end{abstract}

Results: Characteristics study for variables of age, occupation, parity, education, episiotomy and neonates weight showed homogeneous characteristics. The mean duration of the third stage for all groups was between $366.7 \pm 159.0$ seconds and $440.1 \pm 244.99$ seconds. While the average number of postpartum haemorrhage for all group $61.894 \pm 226.3 \mathrm{ml}$ and $309.5 \pm 110.26 \mathrm{ml}$. There were no differences in the dose of oxytocin on the duration of the third stage $(p>0.05)$ and the amount of bleeding ( $p>0.005)$. There was a difference of haemoglobin between intervention group of oxytocin dose of $10 \mathrm{IU}$ and $30 \mathrm{IU}$ intraumbilical $(\mathrm{p}=0.031)$. There was no difference between the mean hematocrit levels between the groups ( $>>0.005)$.

Conclusion: There were no differences in the dose of oxytocin intraumbilical towards the duration of the third stage, the amount of bleeding and hematocrit levels. The decrease of haemoglobin greater in $30 \mathrm{IU}$ intraumbilical significantly.

[Indones J Obstet Gynecol 2018; 6-3: 155-161]

Keywords: duration of the third stage, haemoglobin and hematocrit, oxytocin intraumbilical, the amount of bleeding

\begin{abstract}
Abstrak
Tujuan: Membandingkan dosis injeksi oksitosin intraumbilikal terhadap lama kala III, jumlah perdarahan pascasalin, hemoglobin dan hematokrit.

Metode: Penelitian ini merupakan uji klinis acak dengan pembanding. Kelompok kontrol diberikan injeksi oksitosin 10 IU intramuskular. Intervensi pada 3 kelompok yaitu kelompok perlakuan oksitosin intraumbilikal dosis $10 \mathrm{IU}, 20 \mathrm{IU}$ dan $30 \mathrm{IU}$ yang dilarutkan dalam saline 0,9\% sebanyak $50 \mathrm{ml}$ yang diinjeksikan pada vena umbilikal. Pemilihan sampel secara purposive sampling dan pembagian kelompok berdasarkan sistematik random sampling (10 sampel tiap kelompok). Data diambil periode April 2016 - Januari 2017 dengan kriteria inklusi dan eksklusi. Data dianalisis dengan uji Chi square, uji T, Anova dan Post hoc test.

Hasil: Karakteristik umum variabel usia, pekerjaan, paritas, pendidikan, episiotomi dan berat badan neonatus menunjukkan karakteristik homogen. Rerata lama kala III untuk semua kelompok adalah antara 366,7 $\pm 159,0$ detik dan 440,1 $\pm 244,99$ detik. Sedangkan rerata jumlah perdarahan pascasalin untuk semua kelompok 226,3 $\pm 61,894 \mathrm{ml}$ dan 309,5 $\pm 110,26 \mathrm{ml}$. Tidak ada perbedaan dosis oksitosin terhadap lama kala III $(p>0,05)$ dan jumlah perdarahan ( $p>0,005)$. Ada perbedaan rerata hemoglobin setelah intervensi oksitosin dosis $10 \mathrm{IU}$ dan $30 \mathrm{IU}$ intraumbilikal $(p=0,031)$. Tidak terdapat perbedaan rerata kadar hematokrit antara semua kelompok $(p>0,005)$.
\end{abstract}

Kesimpulan: Tidak ada perbedaan dosis oksitosin intraumbilikal terhadap lama kala III, jumlah perdarahan dan kadar hematokrit. Ada perbedaan rerata hemoglobin setelah intervensi oksitosin dosis 10 IU dan 30 IU intraumbilikal.

[Maj Obstet Ginekol Indones 2018; 6-3: 155-161]

Kata kunci: hemoglobin dan hematokrit, jumlah perdarahan, lama kala III, oksitosin intraumbilikal

Correspondence: Nurul Islamy,: nurulislamy@gmail.com

\section{INTRODUCTION}

Postpartum haemorrhage (PPH) is a major cause of maternal mortality worldwide with an estimated mortality rate of 140,000 per years. The incidence of postpartum haemorrhage in developed countries is $5 \%$ of deliveries, while in developing countries is $28 \%$ of labour. The causes maternal mortality of postpartum haemorrhage are due to $80 \%$ uterine atony and $10 \%$ retained placenta. Most of these deaths occur within 4 hours after delivery, is a consequence of the third stage of labor. $^{1-3}$

Indonesian Demographic Health Survey in 2012 showed the maternal mortality rate increased from 
228 per 100,000 live births in 2007 to 359 per 100,000 live births in $2012 .^{2}$ The leading causes of maternal mortality in Indonesia is postpartum haemorrhage (28\%), eclampsia (24\% ) and infections $(11 \%)$. Postpartum haemorrhage is bleeding, or blood loss of more than $500 \mathrm{ml}$ which occurred after the child is born either before, during, or after birth placenta. $^{2-4}$

To prevent postpartum haemorrhages carried out active management of the third stage. Active management of the third stage consists of the injection of oxytocin 10 IU intramuscularly (IM), massage of uterine fundus and cord traction to accelerate the delivery of placenta by inducing uterine contractions. ${ }^{4,5}$

Oxytocin can be given intramuscularly or intraumbilically. The route of intraumbilical oxytocin will be distributed directly to the oxytocin receptors in the myometrium thereby the myometrium will contract better. ${ }^{4,6,7}$ Result analysis showed that the active management of the third stage could reduce postpartum haemorrhage up to $58 \%{ }^{6,7}$ Cochrane reviewed the active management of the third stage reduces the incidence of postpartum bleeding, shorten the third stage and the need for trasfusion. ${ }^{4-6}$

\section{METHODS}

This study was a randomised study with a control. Intervention in the three groups of intraumbilical oxytocin treatment with the dose of $10 \mathrm{IU}, 20 \mathrm{IU}$ and $30 \mathrm{IU}$ diluted in normal saline $50 \mathrm{ml}$ injected into the umbilical vein. The control group was given an intramuscular injection of 10 IU oxytocin. This research was conducted in the Department of Obstetrics and Gynecology Hospital Dr. Moh. Hoesin, Palembang. The research was conducted in April 2016 to January 2017. The study population was all pregnant women who gave birth in Department of Obstetrics and Gynecology Hospital. Dr. Mohammad Hoesin / Faculty of Medicine, Universitas Sriwijaya Palembang. The samples were all pregnant women who gave birth, qualified inclusion and exclusion criteria.

Sampling was done by purposive sampling and divided into control group and intervention group by systematic random sampling. Sample size calculations with Pocock formula. The number of samples obtained each study group were ten respondents. The inclusion criteria were pregnant women without complication (physiologically), premature rupture of membranes (PROM) $<12$ hours. Exclusion criteria of obesity with a body mass index (BMI) of $35 \mathrm{~kg} / \mathrm{m}^{2}$, abnormal uterine (eg, anatomical abnormalities, fibroids), a blood disorder in the mother (Von Willebrand disease, idiopathic thrombocytopenia purpura, disseminating intravascular coagulation (DIC)), placental abruption or placenta previa, multiple pregnancy, polyhydramnios, estimated fetal weight $>3500 \mathrm{~g}$, hypertension or preeclampsia, history of PPH or retained placenta, a history cesarean section or laparotomy and fetal death.

\section{Material}

The materials were disposable syringes $50 \mathrm{ml}$ Terumo, disposable syringe $3 \mathrm{ml}$ ONEMED, oxytocin $10 \mathrm{IU}$ (brand Syntocinon ${ }^{\circledR}$ produced by Novartis), saline solution $0.9 \%$ (manufactured by PT Widatra Bhakti), stopwatch Kadio KD-2005, glassware Pyrex, digital scales (brand Camry), sterile gauze and cloth mat or underpad COSMO Med.

\section{Procedures}

Subjects were randomised systematically by the arrival of the patient. The subject of the first sequence to 10 specified in the control group of 10 samples, and the subject of the order of 11 to 20 in the Intervention group $10 \mathrm{IU}$ intraumbilical and so on until 40 samples. All samples were checked haemoglobin and hematocrit on admission and 2 hours after delivery.

The intervention group after delivered and clamped umbilical cord was first injected $10 \mathrm{IU}$ oxytocin were diluted in $50 \mathrm{ml}$ of normal saline solution to the umbilical vein with the distance of about $10 \mathrm{~cm}$ from the vulva. The second intervention group were injected 20 IU oxytocin were dissolved in $50 \mathrm{ml}$ of normal saline solution. The third intervention group 30 IU oxytocin dissolved in $50 \mathrm{ml}$ of normal saline solution. Then do massage cord proximally to the spread of oxytocin to the placental implantation site. The control group was injected 10 IU oxytocin intramuscular using a $3 \mathrm{ml}$ disposable syringe lateral upper thigh.

The duration of the third stage is counted starting after birth neonates, injection of oxytocin IM or intraumbilical until the placenta is born with 
a stopwatch. The amount of bleeding is calculated by measuring the blood by using a measuring cup, then under a cloth or gauze pad and used weighed. The difference in weight on a sterile pad (underpad) and gauze before and after use was converted into $\mathrm{ml}(1 \mathrm{~g}=1 \mathrm{ml})$, then weighed with scales Camry models NS.

\section{Analysis and Interpretation}

Data were analysed using Chi-square, T-test, ANOVA and Post hoc.

\section{RESULT}

Experimental research design with pre and posttest with control to compare the dose injection of oxytocin intraumbilical was conducted in April 2016 until January 2017 at the General Hospital
Dr. Mohammad Hoesin Palembang. Total samples of 40 pregnant women who delivered and fulfilled the inclusion criteria. The amount of bleeding, duration of the third stage, haemoglobin and hematocrit each control group and the intervention will be assessed and compared.

\section{Characteristics of Subjects}

The range of respondents age was 14-45 years, and the largest age group was 20-35 years old as many as 32 samples (80\%). The majority of respondents do not work or as housewives (92.5\%). The majority of parity was primigravida (47.5\%) with a high school education level was $80 \%$. Majority of $60 \%$ respondents done episiotomy with the average birth weight of newborns in this study were $2949 \pm 282.95$ gram (Table 1 ).

Table 1. Characteristics of Subjects

\begin{tabular}{|c|c|c|c|c|c|c|}
\hline Characteristics & $\begin{array}{c}\text { Oxytocin } \\
10 \mathrm{IU} \\
\text { intramuscular } \\
(\%)\end{array}$ & $\begin{array}{c}\text { Oxytocin } \\
10 \mathrm{IU} \\
\text { intraumbilical } \\
(\%)\end{array}$ & $\begin{array}{c}\text { Oxytocin } \\
20 \mathrm{IU} \\
\text { intraumbilical } \\
(\%)\end{array}$ & $\begin{array}{c}\text { Oxytocin } \\
30 \mathrm{IU} \\
\text { intraumbilical } \\
(\%)\end{array}$ & Total & p-value \\
\hline \multicolumn{7}{|l|}{ Age (years old)* } \\
\hline$<20$ & $1(25)$ & $1(25)$ & $1(25)$ & $1(25)$ & $4(100)$ & 0.254 \\
\hline $20-35$ & $8(25)$ & 9 (28.1) & 7 (21.9) & $8(25)$ & $32(100)$ & \\
\hline$>35$ & $1(25)$ & 0 & $2(50)$ & $1(25)$ & $4(100)$ & \\
\hline \multicolumn{7}{|l|}{ Address** } \\
\hline Urban area & $10(31.3)$ & 5 (15.6) & $8(25)$ & 9 (28.1) & $32(100)$ & 0.033 \\
\hline Rural area & 0 & $5(62.5)$ & $2(25)$ & $1(12.5)$ & $8(100)$ & \\
\hline \multicolumn{7}{|l|}{ Occupation* } \\
\hline Housewives & $9(24.3)$ & $10(27)$ & $8(21.6)$ & $10(27)$ & $37(100)$ & 0.158 \\
\hline Private sector & $1(100)$ & 0 & 0 & 0 & $1(100)$ & \\
\hline Teacher & 0 & 0 & $2(100)$ & 0 & $2(100)$ & \\
\hline \multicolumn{7}{|l|}{ Parity* } \\
\hline 0 & $5(26.3)$ & $7(36.8)$ & $3(13.8)$ & $4(21.1)$ & $19(100)$ & 0.515 \\
\hline 1 & $4(36.4)$ & $1(9.1)$ & $2(18.2)$ & $4(36.4)$ & $11(100)$ & \\
\hline 2 & $1(14.3)$ & $2(28.6)$ & 3 (42.9) & $1(14.3)$ & $7(100)$ & \\
\hline$\geq 3$ & 0 & 0 & $2(66.6)$ & $1(33.4)$ & $3(100)$ & \\
\hline \multicolumn{7}{|l|}{ Education* } \\
\hline Elementary & 0 & 0 & $2(100)$ & 0 & $2(100)$ & 0.061 \\
\hline Junior High & $2(100)$ & 0 & 0 & 0 & $2(100)$ & \\
\hline Senior High & 5 (15.6) & $10(31.2)$ & 7 (21.9) & $10(31.2)$ & $32(100)$ & \\
\hline $\mathrm{D} 3 / \mathrm{S} 1$ & $3(75)$ & 0 & $1(25)$ & 0 & $4(100)$ & \\
\hline \multicolumn{7}{|l|}{ Episiotomy** } \\
\hline Yes & $6(25)$ & 8 (33.3) & 4 (16.7) & $6(25)$ & $24(100)$ & 0.343 \\
\hline No & $4(25)$ & $2(12.5)$ & $6(37.5)$ & $4(25)$ & $16(100)$ & \\
\hline $\begin{array}{l}\text { Birth weight } \\
\text { neonates }\end{array}$ & $3.085 \pm 316.27$ & $2.860 \pm 307$ & $2.890 \pm 261.19$ & $2.960 \pm 282$ & & 0.297 \\
\hline
\end{tabular}




\section{Duration of the third stage}

The mean time of the third stage for all groups was between (366.7 \pm 159.0 seconds) and (440.1 \pm 244.99 seconds). Mann-Whitney test showed the distribution of data not normal, followed by a test of Kruskal Wallis. From the results of Kruskal Wallis showed there was no difference between all the intervention group ( $p=0.492)$. It can be concluded that there was no difference in the duration of the third stage among the control group (oxytocin dose of 10 IU IM) with oxytocin intraumbilical all doses groups (Table 2).

\section{The Blood Loss during The Third Stage}

Post Hoc test results obtained probability between the control group (oxytocin dose of 10 IU IM) at a dose of $10 \mathrm{IU}$ oxytocin group intraumbilical, a dose of 20 IU oxytocin intraumbilical, and a dose of 30 IU oxytocin intraumbilical ( $p>0.05$ ). It can be concluded that there was no difference in the number of blood lossamong the control group (oxytocin dose of 10 IU IM) and intervention intraumbilicalgroups in all doses of oxytocin significantly.

Table 2. Comparison of Intraumbilical Oxytocin Dose in the Duration of the Third Stage between the Two Groups

\begin{tabular}{|c|c|c|c|c|}
\hline Groups & Average \pm SD & Groups & Average \pm SD & p-value \\
\hline \multirow[t]{3}{*}{ Oxytocin dose 10 IU IM } & $401.4 \pm 209.48$ & $\begin{array}{l}\text { Oxytocin dose } 10 \text { IU } \\
\text { Intraumbilical }\end{array}$ & $366.7 \pm 159.09$ & 0.791 \\
\hline & & $\begin{array}{l}\text { Oxytocin dose } 20 \text { IU } \\
\text { Intraumbilical }\end{array}$ & $440.1 \pm 244.99$ & 0.384 \\
\hline & & $\begin{array}{l}\text { Oxytocin dose } 30 \mathrm{IU} \\
\text { Intraumbilical }\end{array}$ & $384.7 \pm 314.59$ & 0.185 \\
\hline \multirow[t]{2}{*}{$\begin{array}{l}\text { Oxytocin dose } 10 \mathrm{IU} \\
\text { Intraumbilical }\end{array}$} & $366.7 \pm 159.09$ & $\begin{array}{l}\text { Oxytocin dose } 20 \mathrm{IU} \\
\text { Intraumbilical }\end{array}$ & $440.1 \pm 244.99$ & 0.427 \\
\hline & & $\begin{array}{l}\text { Oxytocin dose } 30 \text { IU } \\
\text { Intraumbilical }\end{array}$ & $384.7 \pm 314.59$ & 0.570 \\
\hline $\begin{array}{l}\text { Oxytocin dose } 20 \text { IU } \\
\text { Intraumbilical }\end{array}$ & $440.1 \pm 244.99$ & $\begin{array}{l}\text { Oxytocin dose } 30 \mathrm{IU} \\
\text { Intraumbilical }\end{array}$ & $384.7 \pm 314.59$ & 0.096 \\
\hline
\end{tabular}

Mann Whitney, Kruskal Wallis

Table 3. Comparison of Intraumbilical Oxytocin in Blood Loss, Haemoglobin and Hematocrits to All Groups.

\begin{tabular}{|c|c|c|c|c|}
\hline Primary outcome & $\begin{array}{l}\text { Oxytocin } 10 \text { IU } \\
\text { intramuscular } \\
\text { (Group 1) }\end{array}$ & $\begin{array}{l}\text { Oxytocin } 10 \text { IU } \\
\text { intramuscular } \\
\text { (Group 2) }\end{array}$ & $\begin{array}{l}\text { Oxytocin 20 IU } \\
\text { intramuscular } \\
\text { (Group 3) }\end{array}$ & $\begin{array}{l}\text { Oxytocin } 30 \mathrm{IU} \\
\text { intramuscular } \\
\text { (Group 4) }\end{array}$ \\
\hline $\begin{array}{l}\text { Blood loss, } \mathrm{ml} \\
\mathrm{p} \text { value }\end{array}$ & $\begin{array}{l}309.5 \pm 110.26 \\
1 \text { vs } 2=0.051 \\
1 \text { vs } 3=0.952 \\
1 \text { vs } 4=0.407\end{array}$ & $\begin{array}{l}226.3 \pm 61.894 \\
2 \text { vs } 3=0.058 \\
2 \text { vs } 4=0.244\end{array}$ & $\begin{array}{l}307.0 \pm 86.929 \\
3 \text { vs } 4=0.442\end{array}$ & $275.0 \pm 101.57$ \\
\hline $\begin{array}{l}\text { Difference in haemoglobin level }(\mathrm{g} / \mathrm{dl}) \\
\mathrm{p} \text { value }\end{array}$ & $\begin{array}{l}0.27 \pm 0.79 \\
1 \text { vs } 2=0.840 \\
1 \text { vs } 3=0.230 \\
1 \text { vs } 4=0.256\end{array}$ & $\begin{array}{l}0.35 \pm 0.43 \\
2 \text { vs } 3=0.315 \\
2 \text { vs } 4=0.183\end{array}$ & $\begin{array}{l}0.33 \pm 0.72 \\
3 \text { vs } 4=0.023\end{array}$ & $0.65 \pm 0.75$ \\
\hline $\begin{array}{l}\text { Difference in hematocrit level (\%) } \\
\text { p value }\end{array}$ & $\begin{array}{l}0.60 \pm 2.41 \\
1 \text { vs } 2=0.628 \\
1 \text { vs } 3=0.505 \\
1 \text { vs } 4=0.278\end{array}$ & $\begin{array}{l}1.50 \pm 1.58 \\
2 \text { vs } 3=0.855 \\
2 \text { vs } 4=0.121\end{array}$ & $\begin{array}{l}0.80 \pm 1.99 \\
3 \text { vs } 4=0.085\end{array}$ & $1.90 \pm 2.51$ \\
\hline
\end{tabular}

Post Hoc test (LSD test), $p=0.005$

Mean $\pm S D$ 


\section{Comparison of Dose Oxytocin to Haemo- globin}

Post Hoc test probability between the control group (oxytocin dose of $10 \mathrm{IU}$ IM) at a dose of 10 IU oxytocin group intraumbilical, a dose of $20 \mathrm{IU}$ oxytocin intraumbilical, and a dose of $30 \mathrm{IU}$ oxytocin intraumbilical $>0.05$. There was no difference between the average amount of bleeding control (doses of 10 IU oxytocin IM) with all doses of oxytocin intraumbilical significantly. In addition, the results obtained probability value was 0.023 between the 20 and 30 IU oxytocin intraumbilical $(\mathrm{p}<0.05)$. There was difference haemoglobin level of 30 IU oxytocin group intraumbilical lower than the oxytocin group 20 IU intraumbilical.

\section{Comparison of Dose Oxytocin to Hema- tocrit Levels}

Post Hoc test results obtained probability between the positive control group (oxytocin dose of 10 IU IM) with all doses of oxytocin group intraumbilical $(p>0.05)$. There was no difference of mean hematocrit levels among the control group with the intervention group intraumbilical all doses of oxytocin significantly.

\section{DISCUSSION}

General characteristics of Chakra research revealed no significant differences in age, education level and occupation of respondents.9,10,12 In the study Movahed was no significant difference between the parity of the respondents $(p=0.632)$ with the characteristics of the respondents there are many primigravid (46\%). ${ }^{9,10,15}$

Episiotomy was performed in $60 \%$ of respondents with average birth weight of newborns $2949 \pm 282.95$ grams. Research of Movahed were mean weight neonates $3303.8 \pm$ 366.3. Statistically, there was no significant difference between the variables an episiotomy or not $(\mathrm{p}=0.244)$ with weight neonates $(\mathrm{p}=$ $0.782){ }^{11,12}$

Based on the analysis there were no significant differences in age, occupation, parity, education, episiotomy and weight neonates. The variable addressed indicates significant value. Characteristics of research subjects, in general, have a homogenous result.
The longest duration of the third stage found in groups of 20 IU oxytocin intraumbilical dose and shortest found in the oxytocin group an intraumbilical dose of 10 IU. From the statistical analysis, Mann-Whitney and Kruskal Wallis test showed there was no difference duration of the third stage between groups ( $p>0.05)$. The results of this study are supported by Movahed research conducted in 2012 showed a statistically significant in the oxytocin intraumbilical group could shorten the time of the third stage than the control group ( $4.2 \pm 4: 11$ vs $4: 52 \pm 5: 53 \mathrm{~min} ; \mathrm{p}=0.031$ ). Neither Puri study conducted in 2012 reported that oxytocin intraumbilical significant reduction in the duration of the third stage of labour at five study groups. $5,6,10$

Highest blood loss was found in the group of an intramuscular dose of $10 \mathrm{IU}$ oxytocin, and the least amount of bleeding was found in the group intraumbilical dose of 10 IU oxytocin. Statistical analysis of Post Hoc showed there was no difference in the amount of bleeding between the groups ( $p>0.05$ ). Chakra obtained the cut-off point of bleeding in the third stage of $136 \mathrm{ml}$, effective when the third stage of bleeding is less than or equal to $136 \mathrm{ml}$. The effectiveness of bleeding in the third stage on the intraumbilical group by $55 \%$ higher compared to the intramuscular group is at $8.3 \%$, a statistically significant correlation based on the amount of bleeding in the third stage $(\mathrm{p}=$ 0.001 ). Cochrane meta-analysis on 15 studies suggest a significant borderline; there were no differences in the duration of the third stage and the amount of bleeding between the groups with expectative management intraumbilical oxytocin, saline only, intramuscular oxytocin and prostaglandins. Controversial opinion on oxytocin intraumbilical various doses may provide clinical benefit in reducing the length of the third stage and the number of haemorrhage research of Weeks and G. Carroli. 8,9,13

Statistical analysis showed there was no difference between the haemoglobin levels after intervention dose of 10 IU oxytocin and oxytocin IM dose of $20 \mathrm{IU}$ intraumbilical. This means that the dose of $10 \mathrm{IU}$ oxytocin and oxytocin IM dose of $20 \mathrm{IU}$ intraumbilical effective to prevent a decrease in haemoglobin $(\mathrm{p}<0.05)$. While the intervention of oxytocin dose of $10 \mathrm{IU}$ and $30 \mathrm{IU}$ intraumbilical not effectively prevent a decrease in haemoglobin levels was statistically significant $(p>0.05)$. These results indicate a dose of oxytocin intraumbilical 
small and large are not effective to prevent a decrease in haemoglobin. Increasing doses of oxytocin intraumbilical more than 20 IU will lead to lower haemoglobin levels significant.

In addition to haemoglobin, changes in hematocrit levels were also assessed in this study. Statistical analysis showed that there was difference between the mean hematocrit levels after intervention dose of 10 IU oxytocin and oxytocin IM dose of 20 IU intraumbilical. A dose of 10 IU oxytocin and oxytocin IM dose of 20 IU intraumbilical effective to prevent a decrease in hematocrit $(\mathrm{p}>0.05)$. While the intervention group oxytocin dose of 10 IU and 30 IU intraumbilical not effectively prevent a decrease in hematocrit seen from a decrease in hematocrit levels were statistically significant $(\mathrm{p}<0.05)$. These results indicated a dose of oxytocin intraumbilical small and large were not effective to prevent a decrease in hematocrit. Increasing doses of oxytocin intraumbilical more than 20 IU would decrease hematocrit levels. $7,8,10$

The absence of a significant decrease in haemoglobin and hematocrit levels in the intervention group a dose of 10 IU oxytocin and oxytocin IM dose of 20 IU intraumbilical indicate that this intervention can prevent postpartum bleeding. ${ }^{7,8,14,15}$

Post hoc tests showed the effectiveness of all doses of oxytocin intraumbilical no different from the effectiveness of the control of oxytocin. However, the effectiveness of a dose of 30 IU oxytocin intraumbilical significantly different with a dose of 20 IU oxytocin intraumbilical. Haemoglobin and hematocrit levels after intervention intraumbilical dose of 30 IU oxytocin lower than the levels of haemoglobin and hematocrit after intervention intraumbilical dose of 20 IU oxytocin so that it can be concluded extra doses of oxytocin intraumbilical more than 20 IU would not prevent a decrease in haemoglobin levels and hematocrit.7,8,15

In theory, exposure to high doses of oxytocin cause desensitisation and down-regulation on the oxytocin receptor. Oxytocin receptors are a group of $\mathrm{G}$ protein-coupled receptors (GPCRs). Desensitization is a process that prevents overstimulation on cells through two mechanisms. First with the receptor phosphorylation inhibits the activation of protein G. Both with binding proteins, called arrestins, preventing activation of the $G$ protein that did not happen with the oxytocin receptor binding. 13,15

Research Anisodowleh comparing haemoglobin in the intervention group with oxytocin 10 IU dissolved in $20 \mathrm{ml}$ saline compared with oxytocin $20 \mathrm{IU}$ in a solution of Ringer's lactate $1 \mathrm{l}$ at 100 $\mathrm{ml} / \mathrm{min}$ intravenously, showed haemoglobin level was $12.45 \pm 0.78 \mathrm{~g} / \mathrm{dl}$ and $12.49 \pm 0.85 \mathrm{~g} / \mathrm{dl}$ $(p=0782)$. Haemoglobin levels after 6 hours of labour are higher in the intervention group compared to the control group $12.32 \pm 0.88 \mathrm{~g} / \mathrm{dl}$ vs $11.58 \pm 0.86 \mathrm{~g} / \mathrm{dl}$, but this difference was not significant $(\mathrm{p}=0.23)$. A decrease haemoglobin concentration from $1.96 \mathrm{~g} / \mathrm{dl}$ to $1.2 \mathrm{~g} / \mathrm{dl}$ in the intervention group and the control that shows a positive effect on injection of oxytocin intraumbilical. The differences are not significant due to the active management of the third stage in the two groups was performed using a uterotonic and standards procedure. $8,11,12$

Research Movahed et al. described the decrease of haemoglobin levels in the intervention group who received injections of oxytocin is intraumbilical not significantly different with the control group who received intravenous oxytocin $(p=0.228)$. So that the injection of oxytocin intraumbilical concluded no benefit in preventing postpartum haemorrhage quantified grading Hb. $6,7,10$

Puri results explained the significant differences in levels of haemoglobin and hematocrit on four intervention groups and one control group. The concentration of $10 \mathrm{IU}$ oxytocin increased in groups of 2 to $20 \mathrm{IU}$ in group 3, further reduction of time in the third stage but the difference was not statistically significant. Oxytocin concentrations increased to $30 \mathrm{IU}$ (or $0.06 \mathrm{IU} / \mathrm{ml}$ ) in group 4 significantly reduced the volume of blood, and there were differences in haemoglobin concentration and hematocrit before and after childbirth. ${ }^{6}$

Limitations of this study were the small sample number and not blinded when the retrieval and analysis of data. Measurement of the amount of bleeding was based on the amount of bleeding that accommodated (underpad, gauze). It was subjective, not using the colourimetric technique, radiolabeled red blood cells, gravimetric or dye dilution method. 


\section{CONCLUSION}

Oxytocin intraumbilical $10 \mathrm{IU}$ reduced the duration of the third stage and blood loss. There were no differences in the duration of the third stage, volume blood loss and hematocrit level among the control group (oxytocin dose of 10 IU IM) with oxytocin intraumbilical all dose groups significantly. However, there was a difference between the mean haemoglobin levels of 20 and $30 \mathrm{IU}$ oxytocin, whereby haemoglobin levels $30 \mathrm{IU}$ oxytocin group intraumbilical lower than $20 \mathrm{IU}$ oxytocin group intraumbilical.

\section{SUGGESTION}

Oxytocin intraumbilical10 IU could be an alternative in the active management of the third stage an action that was not invasive to the mother, easy, cheap and minimal side effects to prevent postpartum bleeding. The results are expected to be used as basic data for more advanced research, using the number of subjects a larger study and consider the factors that may be a bias in this study.

\section{REFERENCES}

1. Badan Koordinasi Keluarga Berencana Nasional (BKKBN). Survey Demografi dan Kesehatan Indonesia (SDKI). Jakarta. Profil Kesehatan Indonesia. 2012.

2. Cunningham FG, Leveno KJ, Bloom SL, Hauth JC, Rouse DJ, Spong CY. Williams Obstetrics. 24th ed. New York: McGrawHill Companies Inc. 2015: 780-804.

3. Nardin JM, Weeks A, Carolli G. Umbilical vein injection for management of retained placenta (Review). Cochrane Collaboration. 2012: 1-65.

4. Carroli G, Belizan JM, Grant A, Gonzalez L, Campodonico L, Bergel E. Intraumbilical vein injection and retained placenta: evidence from a collaborative large randomized controlled trial. Br J Obstet Gynaecol. 1998; 105: 179-85.
5. Weeks A, Alia G, Vernon G, Namayanja A, Gosakan R, Majeed $\mathrm{T}$, et al. Umbilical vein oxytocin for the treatment of retained placenta (Release Study): A double-blind, randomised controlled trial. Lancet. 2010; 375: 141-7.

6. Puri M, Taneja P, Gami N, Rehan HS. Effects of different doses of intraumbilical oxytocin on the third stage of labor. Int J Gynecol Obstet. 2012; 118(3): 210-2.

7. Anisodowleh N, Farahnaz K, Taravat F, Shamsy Z, Mansour $\mathrm{R}$, Sara D. Effect of intraumbilical vein oxytocin injection on third stage of labor. Taiwanese J Obstet Gynecol. 2013: 5760.

8. Habek D, Franicevic D. Intraumbilical injection of uterotonics for retained placenta. Int J Gynecol Obstet. 2007: 105-9.

9. Chakra A. Perbandingan antara injeksi oksitosin intravena umbilikalis dibandingkan dengan injeksi oksitosin intramuskular pada penanganan kala III. Tesis. Bagian Obstetri dan Ginekologi Fakultas Kedokteran Universitas Sriwijaya. 2008.

10. Movahed F, Nejhad RR, Javadi E, Lalooha F, Mashrabi 0. Efficacy of intraumbilical vein (IUV) injection of oxytocin in active management of the third stage of labor. Life Sci J. 2012: 1242-2246.

11. Bider D, Dulitzky M, Goldenberg M, Lipitz S, Mashiach S. Intraumbilical vein injection of prostaglandin in retained placenta. Eur J Obstet Gynecol Reprod Biol. 1996; 64: 59-61.

12. Huber MGP, Wildschut HU, Boer K, Kleiverda G, Hoek FJ. Umbilical vein administration of oxytocin for the management of retained placenta: is it effective?. Am J Obstet Gynecol. 1991; 164: 1216-19.

13. Dildy GA, Paine AR, George NC, Velasco C. Estimating blood loss: can teaching significantly improve visual estimation?. Obstet Gynecol. 2004; 104(3): 601-6.

14. Pedoman Nasional Pelayanan Kedokteran. Perdarahan Pascasalin. Perkumpulan Obstetri dan Ginekologi Indonesia Himpunan Kedokteran Fetomaternal. Jakarta. 2015.

15. Güngördük K, Asicioglu O, Besimoglu B, Güngördük $O C$, Yildirm G, Ark C, et al. Using intraumbilical vein injection of oxytocin in routine practice with active management of the third stage of labor: a randomized controlled trial. Obstet Gynecol 2010; 116(3): 619-24.

16. Chantrapitak W, Srijuntuek K, Wattanaluangarun R. The efficacy of lower uterine segment compression for prevention of early postpartum hemorrhage after vaginal delivery. J Med Assoc Thai. 2011; 94(6): 649-56. 